\title{
BIODEGRADASI DAN MORFOLOGI POLIPADUAN GRAFTING LDPE TAPIOKA DENGAN INISIATOR DICUMIL PEROKSIDA
}

\section{(BIODEGRADABLE AND MORPHOLOGY LDPE-TAPIOCA BLENDS GRAFTING USING DYCUMIL PEROXIDE AS INISIATOR)}

\author{
Arum Yuniari ${ }^{1)}$ \\ Email: arumyuniari@yahoo.com \\ Diterima: 8 Agustus 2011 \\ Disetujui: 15 Nopember 2011
}

\begin{abstract}
Biodegradable plastics can be made by grafting LDPE and tapioca using dycumil peroxide as initiator and maleic anhydride as compatibilizer. Maleic anhydride grafting on LDPE is one way to make LDPE more polar so it will easily hydrolyzed and oxidized. The research objective was to determine the changes in physical properties and morphology of LDPE/tapioca grafting before and after burial in soil. The mixing process was done by Rheocord (Haake 90). The sample compositions of LDPE/tapioca were: 80/20; 75/25; 70/30; 65/35 and 60/40. Biodegradation test was conducted by burial in soil for 120 days with 30 days of observation time. To observe physical properties changes, SEM and FTIR tests were performed before and after burial in soil. The results showed that after burial in soil, the tensile strength and elasticity were decreased and the rate of weight loss was increased. The highest percentage of weight loss occurs in the samples with ratio of LDPE/tapioca of 60/40, which was $55.89 \%$ after burial for 120 days. The result of the infrared spectrophotometer (FTIR) test showed no change of functional groups before and after burial in soil. Observations by SEM test on the surface of the LDPE/tapioca poliblend after burial in soil showed no pits / holes at the surface.
\end{abstract}

Keywords: biodegradation, LDPE, tapioca, maleic anhydride, dicumyl peroxide

\begin{abstract}
ABSTRAK
Plastik biodegradasi dapat dibuat dari grafting LDPE dan tapioka menggunakan inisiator dycumil peroksida dan kompatibiliser maleat anhidrat. Proses pencampuran dilakukan dengan Rheocord (Haake 90). Grafting maleat anhidrat pada LDPE merupakan salah satu cara membuat LDPE menjadi polar sehingga mudah terhidrolisa dan teroksidasi. Tujuan penelitian adalah mengetahui perubahan sifat fisika dan morfologi grafting LDPE/tapioka sebelum dan sesudah pemendaman dalam tanah. Perbandingan LDPE dan tapioka berturut-tururt adalah: 80/20; 75/25; $70 / 30 ; 65 / 35$ dan 60/40. Uji biodegradasi dilakukan dengan pemendaman dalam tanah selama 120 hari dengan waktu pengamatan setiap 30 hari. Pengujian sifat fisika, SEM dan FTIR dilakukan sebelum dan sesudah pemendaman dalam tanah. Hasil penelitian menunjukkan bahwa sesudah pemendaman dalam tanah maka kuat tarik, kemuluran menurun dan laju kehilangan berat makin besar. Prosentase kehilangan berat tertinggi adalah pada perbandingan LDPE/tapioka 60/40 yaitu sebesar 55,89\% dengan waktu pemendaman selama 120 hari. Hasil analisa spectrophotometer infra merah (FTIR) menunjukkan bahwa tidak terjadi perubahan gugus fungsi sebelum dan sesudah pemendaman dalam tanah. Pengamatan dengan SEM permukaan polipaduan LDPE/tapioka sesudah pemedaman dalam tanah tidak rata tampak berlubang-lubang.
\end{abstract}

Kata kunci: biodegradasi, LDPE, tapioka, maleat anhidrat, dicumil peroksida

"Balai Besar Kulit, Karet dan Plastik, Yogyakarta 


\section{PENDAHULUAN}

Produksi plastik didunia tahun 2010 diperkirakan mencapai lebih dari 304 (tiga ratus empat) juta ton per tahun (Anonim, 2010). Kebutuhan bahan plastik lebih unggul dari pada bahan yang lainnya. Salah satu permasalahan penting mengenai lingkungan didunia ataupun di Indonesia khususnya, adalah mengenai sampah plastik. Plastik sangat sulit terdegradasi dialam. Salah satu usaha untuk mengatasi hal ini dengan pembuatan plastik ramah lingkungan. Keberadaan plastik ramah lingkungan sangat diharapkan pada masa kini, terlebih dengan semakin meningkatnya beban lingkungan karena sampah, namun perkembangan plastik ramah lingkungan sangat lambat terutama untuk tujuan komersial. Hal ini disebabkan harga masih mahal dan sifat yang agak lain dari plastik konvensional.

Salah satu metoda pembuatan plastik ramah lingkungan adalah dengan cara penempelan pati pada polietilena (PE) termodifikasi. Salah satu bentuk PE termodifikasi adalah dengan cara penempelan MAH pada rantai molekul PE melalui proses kopolimerisasi tempel (Sunit Hendrana dkk, 2000).

Plastik yang terbiodegradasi merupakan polimer atau campuran polimer yang dapat terhidrolisa oleh enzim atau hancur secara kimiawi, plastik akan terpecah menjadi oligosaccharides atau monomer-monomer melalui depolimerisasi, dan terdegradasi menjadi gas melalui mineralisasi. Plastik yang dapat terbiodegradasi dapat digunakan untuk: pertanian, kemas makanan, pengemas sekali buang (Anonim, 1993).

Beberapa bahan polimer biodegradasi antara lain:

1. Polycaprolactone dibuat oleh Union Carbide dari proses polimerisasi caprolactone (Tokiwa et al, 1990a dan 1990b).

2. Polylactic acid dibuat oleh Cargill, Minneapolis, MN, USA dari proses polimersasi dilactone atau lactic acid.

3. Polybutylene Succinate (PBS) dan Polybutylene Succinate Adipate (PBSA) dibuat oleh Showa Highpolymer Inc., Japan.

4. Polyvinyl alcohol (PVA) merupakan polimer sintetis yang mudah terbiodegradasi (Sakai et al., 1987).

Penelitian tentang plastik ramah lingkungan telah dilakukan oleh beberapa peneliti antara lain: pencampuran plastik dan pati jagung (Zea mays) serta chitosan (limbah cangkang udang) dilaporkan oleh ( Luluk Mufidah dkk, 2008). Plastik ramah lingkungan dari kopolimerisasi tempel malaet anhidrat pada polietilen dan pati dapat menghasilkan plastik lebih murah dan tidak meninggalkan sisa pelarut (Sunit Hendrana dkk, 2000). Takashi Masuda et all (1995) melaporkan bahwa bahan plastik yang dapat terbiodegradasi dapat dihasilkan dari sintesa polyester aliphatic.

Komposit dari grafting LDPE dan pati menggunakan inisiator benzoil peroksida dapat menghasilkan polimer yang dapat terdegradasi sempurna dalam tanah (Inderjeet Kaur dan Neena Gautam, 2010).

Polimer campuran dari bahan yang mengandung bakteri poly(3-hydroxybutyrate) menghasilkan plastik yang dapat terbiodegradasi (Scandola, M.,1995).

Polietilen (PE) terdiri dari berbagai jenis berdasarkan kepadatan dan percabangan molekul. Sifat mekanis dari polietilen (PE) bergantung pada tipe percabangan, struktur kristal dan berat molekulnya. Stuktur molekul dapat dipengaruhi oleh katalis dan kondisi reaksi yang digunakan. Pada suhu dan tekanan rendah dikombinasi dengan katalis logam transisi dihasilkan produk dengan rantai linier dan densitas tinggi (HDPE). Suhu dan tekanan yang lebih tinggi dan dikombinasi dengan katalis jenis peroksida menghasilkan polimer dengan molekul bercabang dan densitas rendah (LDPE).

LDPE (Low Density Polyethylene), merupakan polietilen dengan kisaran densitas antara $0,91-0,94 \mathrm{~g} / \mathrm{cm}^{3}$ dengan cabang-cabang pendek maupun panjang (Gupta, R.K., 1994).

Molekul pati mempunyai rumus kimia $\mathrm{C}_{6} \mathrm{H}_{10} \mathrm{O}_{5}$ terdiri dari amilose dan amilopektin. Pati banyak digunakan sebagai filler dalam pembuatan polimer plastik agar plastik yang dihasilkan cepat mengalami degradasi.

Penambahan pati pada poletilen diharapkan agar mikrobia dapat merusak pati dan akibatnya molekul plastik berpori - pori yang dapat meningkatkan luas permukaan 
molekul polietilen, dan selanjutnya cepat mengalami degradasi.

Polimer dapat merupakan pencampuran yang kompatibel dari dua atau lebih polimer, baik campuran homogen atau heterogen dalam skala mikroskopis. Kompatibilitas merupakan tingkat keterpaduan dari sebuah campuran. Salah satu upaya meningkatkan kompatibitas dapat dilakukan dengan cara memodifikasi permukaan polietilen agar dapat berinteraksi dengan bahan-bahan lain (Chan, 1994; Peacock, 2000). Metoda yang effektif untuk memasukkan sifat-sifat yang diinginkan ke dalam polietilen adalah dengan teknik grafting (tempel/cangkok) (Choi et al., 2003). Kelebihan grafting adalah polietilen dapat difungsionalisasi berdasar sifat monomer yang terikat secara kovalen tanpa mempengaruhi struktur dasar polietilen.

Menurut (Hasnah Muin, 2005) polimer yang bersifat biodegradasi adalah polimer yang pada rantai utamanya mengandung gugus-gugus fungsi yang mudah terhidrolisa atau teroksidasi lanjut oleh enzim. Tujuan penelitian adalah untuk mengetahui perubahan sifat fisika dan morfologi grafting LDPE/tapioka dan maleat anhidrat sebelum dan sesudah biodegradasi.

\section{BAHAN DAN METODE Bahan Penelitian}

Bahan dalam penelitian ini terdiri atas Low Density Polyethylene (LDPE) merk Asrene UI 2650 bentuk butiran dari Jakarta dan bahan pembantu yang digunakan yaitu: tapioka yang diperoleh dari pasaran di yogyakarta dengan ukuran $10 \mathrm{~m} \mu$, maleat anhidrat, asam stearat, gliserol dan dikumil peroksida (DCP) merk Aldrich Chemical Company Inc.

\section{Alat Penelitian}

Alat penelitian terdiri atas neraca analitis (Sartorius tipe BP 4100, kapasitas 200 g, Rheocord (Haake 90), mesin pencacah/grinder, hydraulic press (Toyoseiki, A 652200500), tensile strength tester (KaoTieh, model KT 7010 A, seri 70287, kapasitas $500 \mathrm{~kg}$ ), Scanning Electron Microscopy (SEM) (Jeoul), Fourier Transform Infrared Spertophotometry (FTIR)
(Shimadzu).

\section{Metode Penelitian \\ Rancangan Penelitian}

Untuk mendapatkan plastik ramah lingkungan dari campuran LDPE dan tapioka faktor-faktor yang dipelajari meliputi pengaruh perbandingan LDPE/tapioka berturut-turut: $80 / 20 ; 75 / 25 ; 70 / 30 ; 65 / 35$ dan $60 / 40 \mathrm{phr}$ dengan kompatibiliser maleat anhidrat jumlahnya dibuat tetap yaitu $4 \mathrm{phr}$. Dan sebagai pembanding dibuat kontrol LDPE/tapioka 100/0. Formulasi kompon disajikan pada tabel 1.

Proses pembuatan plastik yang dapat terbiodegradasi dilaksanakan sebagai berikut: pencampuran bahan- bahan dilakukan dalam Rheocord (Haake 90) dengan terlebih dahulu tapioka, asam stearat, DCP dan gliserol dicampur menggunakan internal mixer. LDPE dimasukkan kedalam hopper sambil ditambah maleat anhidrat. Proses blending dilakukan dalam Rheocord (Haake 90) pada suhu $170^{\circ} \mathrm{C}$, kecepatan putar 40 rpm selama 6 menit. Grafik dilayar monitor diamati hingga energi putar menunjukkan konstan.

Tabel 1. Formulasi campuran LDPE-pati

\begin{tabular}{|c|c|c|c|c|c|}
\hline \multirow{2}{*}{ Bahan } & \multicolumn{5}{|c|}{ Jumlah bahan } \\
\cline { 2 - 6 } & F1 & F2 & F3 & F4 & F5 \\
\hline LDPE & 80 & 75 & 70 & 65 & 60 \\
\hline Pati & 20 & 25 & 30 & 35 & 40 \\
\hline Maleat anhidrat & 4 & 4 & 4 & 4 & 4 \\
\hline Asam stearat & 5 & 5 & 5 & 5 & 5 \\
\hline DCP & 2 & 2 & 2 & 2 & 2 \\
\hline Gliserol & 5 & 5 & 5 & 5 & 5 \\
\hline
\end{tabular}

Bila torsi sudah stabil campuran tapioka, asam stearat, DCP dan gliserol masuk kedalam hopper. Amati torsi hingga stabil, kompon plastik yang sudah homogen dikeluarkan dari Rheocord. Kompon plastik diambil dan dikeringkan pada suhu kamar, selanjutnya dimasukkan kedalam alat pencacah (Grinder). Serpihan-serpihan 
kompon plastik dimasukkan alat pelletizing untuk dibuat butiran berbentuk pellet. Pellet plastik dipress dengan alat hydraulic press pada suhu $170^{\circ} \mathrm{C}$, tekanan $150 \mathrm{~kg} / \mathrm{cm}^{2}$ selama 6 menit. Lembaran plastik selanjutnya dipotong sesuai kebutuhan pengujian.

\section{Pengujian}

Pengujian kompon polipaduan LDPE dan tapioka dilakukan terhadap sifat fisis yang meliputi kuat tarik dan kemuluran dan morfologi polipaduan LDPE/tapioka meliputi uji SEM (Scanning Electron Microscopy) dan FTIR pada kondisi awal dan setelah perlakuan pemendaman dalam tanah (biodegradasi). Sampel plastik dengan ukuran cuplikan $10 \times 3$ x $0,2 \mathrm{~cm}$, dipendam dalam tanah dengan interval waktu pengamatan sampel adalah : 30; 60; 90 dan 120 hari. Sebelum dan sesudah penanaman cuplikan ditimbang dan berat yang hilang dihitung.

\section{HASIL DAN PEMBAHASAN}

Pengaruh perbandingan LDPE/tapioka terhadap sifat kuat tarik dan kemuluran awal

Komposisi optimal polipaduan ditentukan berdasarkan sifat fisis bahan terutama pada kuat tarik dan kemuluran. Sifat fisis suatu bahan dipengaruhi oleh sifat alami masing-masing komponen dan kemampuan ikatan dalam senyawa penyusunnya. Hasil uji sifat fisika yang meliputi kuat tarik dan kemuluran menunjukkan besarnya kedua sifat fisis tersebut dipengaruhi oleh kadar tapioka dalam matriks polimer. Gambar 1 dan 2 adalah hasil uji kuat tarik dan kemuluran dipengaruhi oleh jumlah tapioka yang ditambahkan dalam matriks polipaduan, makin banyak kadar tapioka yang ditambahkan kuat tarik dan kemuluran turun, hal ini sesuai dugaan semula bahwa kuat tarik dan kemuluran hanya diberikan oleh polietilen saja, sedang tapioka tidak mempunyai kontribusi pada kuat tarik maupun kemuluran.

Dengan demikian turunnya jumlah LDPE (makin banyak jumlah tapioka) kuat tarik maupun kemuluran juga turun. Hal ini didukung oleh pendapat (Lies A Wisoyodharmo dkk, 2005) dan (Maria Ulfa Christianti, 2009) yang menyatakan bahwa makin besar konsentrasi tapioka ataupun sagu yang ditambahkan ke dalam matrik polietilen maka kekuatan tarik dan kemuluran makin menurun. Kuat tarik maupun kemuluran terendah pada perbandingan LDPE/tapioka $60 / 40$, yaitu sebesar $65,66 \mathrm{~kg} / \mathrm{cm}^{2}$ dan 36,52 $\%$. Penurunan kuat tarik dari polipaduan LDPE dan tapioka disebabkan oleh lemahnya interfacial adhesion tapioka yang bersifat hidrophilic dan tidak kompatibel dengan polimer hidrophobic (Thakore et al,1999).

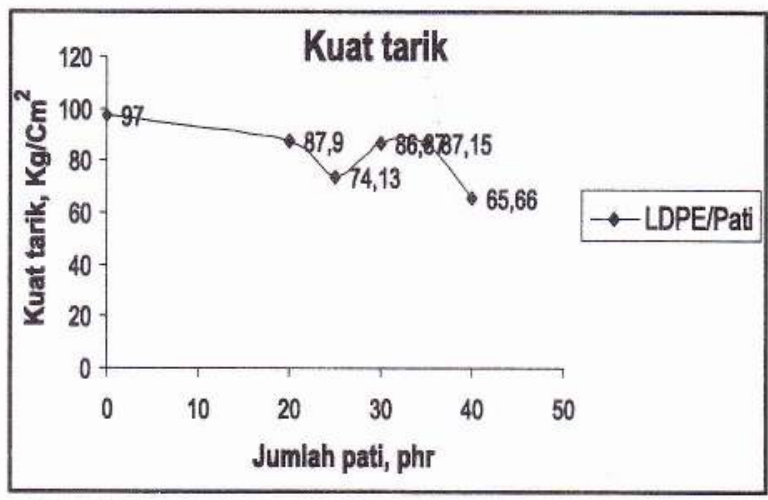

Gambar 1. Kuat tarik polipaduan LDPE dan tapioka

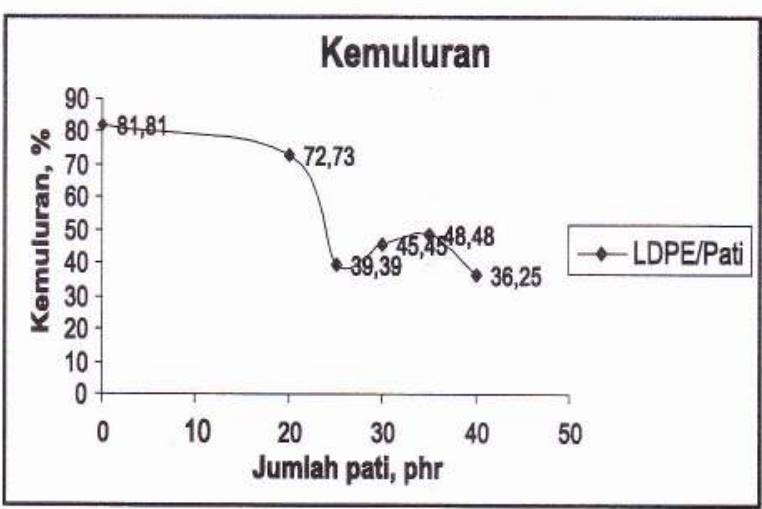

Gambar 2. Kemuluran polipaduan LDPE dan tapioka

Pengaruh waktu pemendaman dalam
tanah terhadap perubahan berat
polipaduan LDPE dantapioka
Biodegradasi grafting LDPE/tapioka diuji melalui pemendaman dalam tanah dan diamati sebagai fungsi waktu, hasilnya disajikan pada Gambar 3. Analisis laju kehilangan berat polimer, pengamatan dilakukan setiap 30 hari. 


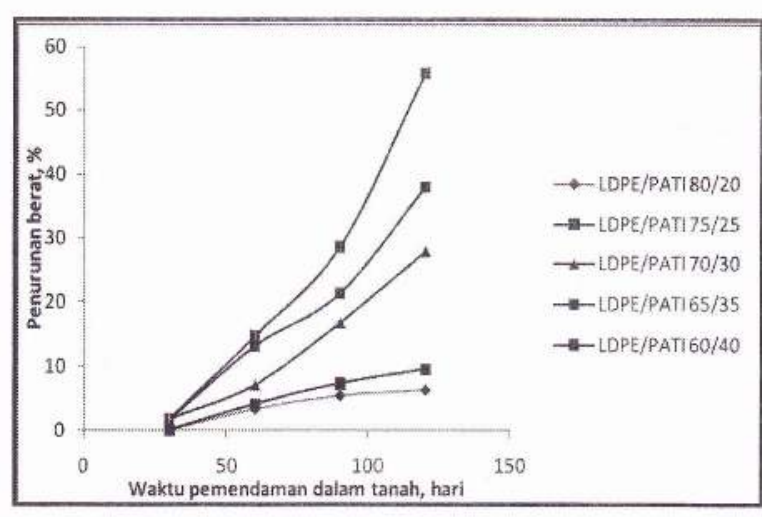

Gambar 3. Laju kehilangan berat polipaduan LDPE dan tapioka

Makin besar penambahan jumlah tapioka pada LDPE menyebabkan kerusakan polimer campuran makin meningkat dengan bertambahnya waktu pemendaman dalam tanah (Gambar 3). Kehilangan berat polimer campuran naik secara tidak linier dengan bertambahnya waktu pemendaman pendapat yang sama disampaikan oleh (Inderjeet Kaur dan Neena Gautam, 2010). Hal ini kemungkinan penyebaran mikroorganisme dalam tanah tidak homogen. Kehilangan berat terbesar dimiliki oleh polipaduan LDPE/tapioka $60 / 40$ dengan lama pemendaman 120 hari yaitu sebesar 55,89 $\%$.

\section{Pengaruh waktu pemendaman terhadap penurunan sifat kuat tarik dan kemuluran}

Uji kuat tarik dan kemuluran terhadap polipaduan LDPE/tapioka sesudah biodegradasi dimaksudkan untuk mengetahui tingkat kerapuhan dari plastik setelah dipendam dalam tanah. Hasil uji penurunan kuat tarik dan kemuluran sesudah pemendaman dalam tanah disajikan dalam Gambar 4 dan 5 .

Gambar 4 dan 5 menunjukkan bahwa variasi waktu pemendaman dalam tanah sangat berpengaruh terhadap sifat kuat tarik dan kemuluran Makin lama waktu pemendaman nilai penurunan kuat tarik dan kemuluran makin besar.

Hal ini kemungkinan disebabkan makin lama waktu pemendaman akan makin banyak terbentuk radikal, pelepasan hidrogen dan akhirnya terjadi pemutusan rantai. Gugusgugus radikal membentuk ikatan silang yang menyebabkan terjadinya pembentukkan gel sehingga kristalinitas polimer turun, akibatnya polimer menjadi kaku dan rapuh. Penurunan kuat tarik dan kemuluran tertinggi selama pemendaman 120 hari dijumpai pada polipaduan LDPE/pati $60 / 40$ yaitu sebesar $62,16 \%$ dan $65,67 \%$. Proses kerusakan polimer campuran dipicu oleh kondisi lingkungan seperti kelembaban, sinar ultraviolet. Pada dasarnya plastik berbasis minyak bumi yang mengandung aditif kimia akan mengalami perubahan signifikan dalam struktur kimianya menjadi partikel ukuran lebih kecil. Makin tinggi konsentrasi tapioka penurunan kuat tarik dan kemuluran setelah pemendaman dalam tanah makin besar. Hal ini didukung oleh (Lies A Wisojodharmo dkk, 2003) mengatakan bahwa makin tinggi jumlah tapioka ditambahkan kerusakan makin besar.

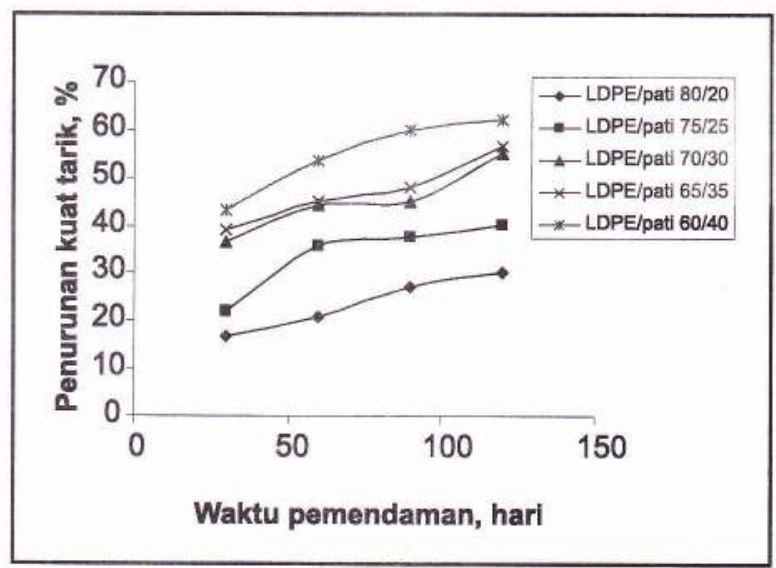

Gambar 4. Grafik penurunan kuat tarik setelah pemendaman dalam tanah

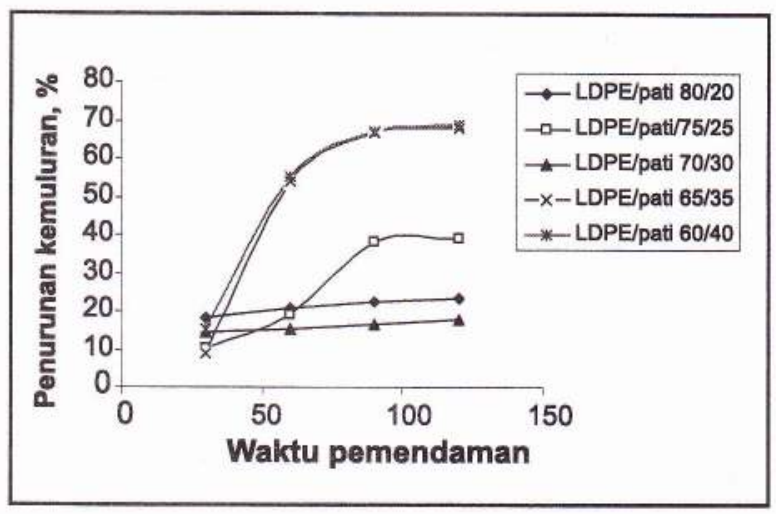

Gambar 5. Grafik kemuluran setelah pemendaman dalam tanah 


\section{Hasil uji Scanning Electron Microscopy}

Morfologi permukaan polipaduan yang disajikan pada Gambar 6 memperlihatkan bahwa bentuk alami tapioka tidak tampak, hal ini mengindikasikan bahwa tapioka bercampur secara homogen. Homogenitas campuran cukup baik ditunjukkan dengan tingkat distribusi fase terdispersi secara merata, namun demikian ikatan interfacial yang terjadi masih belum optimal.

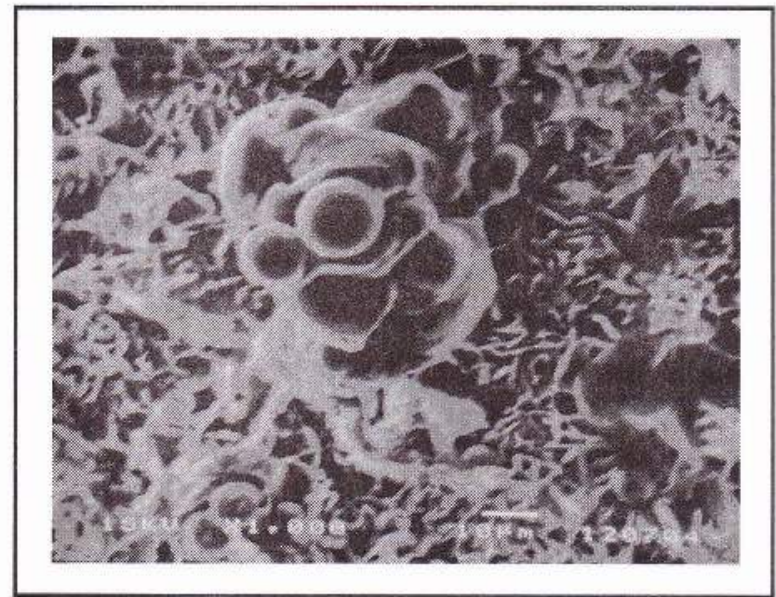

Gambar 6. SEM LDPE/tapioka 80/20 MAH $4 \mathrm{phr}$ sebelum pemendaman dalam tanah perbesaran $1000 \mathrm{x}$

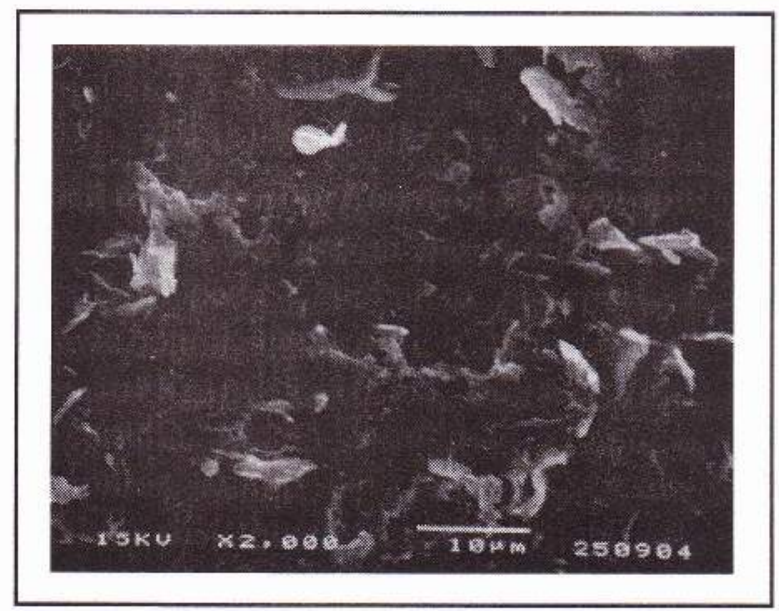

Gambar 7. SEM LDPE/tapioka 80/20 MAH $4 \mathrm{phr}$ sesudah pemendaman dalam tanah perbesaran $1000 \mathrm{x}$

Gambar 7 menyajikan SEM polipaduan yang telah dilakukan pemendaman dalam tanah dan tampak bahwa permukaan sudah tidak merata tampak lubang-lubang, hal ini kemungkinan disebabkan oleh penurunan fibrilitas polipaduan yang ditunjukkan dengan turunnya nilai kuat tarik dan kemuluran.

\section{Karakterisasi polipaduan LDPE/tapioka dengan FTIR}

Metode Fourier Transform Infrared Spectroscopy (FTIR) dimaksudkan untuk mengetahui kualitatif informasi gugus fungsi dan karakteristik kimia dari grafting LDPE /tapioka sebelum dan sesudah pemendaman dalam tanah dan hasil uji disajikan pada Gambar 8 dan 9.

Gambar 8 merupakan hasil spektra FTIR grafting LDPE/tapioka dan maleat anhidrat (MAH). Dari grafik FTIR tampak telah terjadi interaksi antara LDPE + MAH + DCP, hal ini ditunjukkan oleh munculnya puncak serapan panjang gelombang $3417-3453 \mathrm{~cm}^{-1}$ untuk gugus fungsi $\mathrm{O}-\mathrm{H}$ dan 2918-2921 $\mathrm{cm}^{-1}$ khas untuk $\mathrm{CH}_{2}$ dari LDPE dan maleat anhidrat yang didukung puncak serapan panjang gelombang pada daerah 1714 $\mathrm{cm}^{-1}$ untuk gugus karbonil $(\mathrm{C}=\mathrm{O})$ dari maleat anhidrat sedangkan gugus fungsi $\mathrm{H}-\mathrm{C}-\mathrm{H}$ pada panjang gelombang $719 \mathrm{~cm}^{-1}$. Menurut (Chandra dan Rutsgi, 1998) bahwa karakteristik panjang gelombang tersebut menujukkan tapioka terdistribusi secara merata pada matriks plastik. Gambar 9 merupakan grafik FTIR dari grafting LDPE/tapioka dan maleat anhidrat sesudah dilakukan pemendaman dalam tanah.

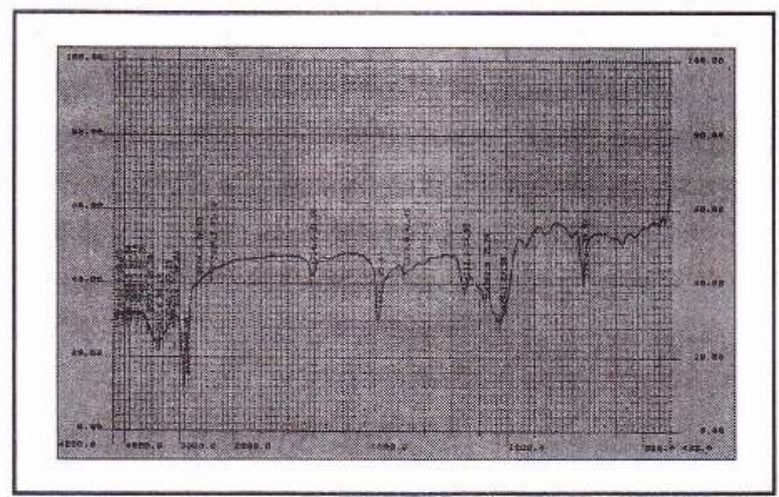

Gambar 8. grafik FTIR LDPE/tapioka $80 / 20$ MAH 4 phr sebelum pemendaman dalam tanah 


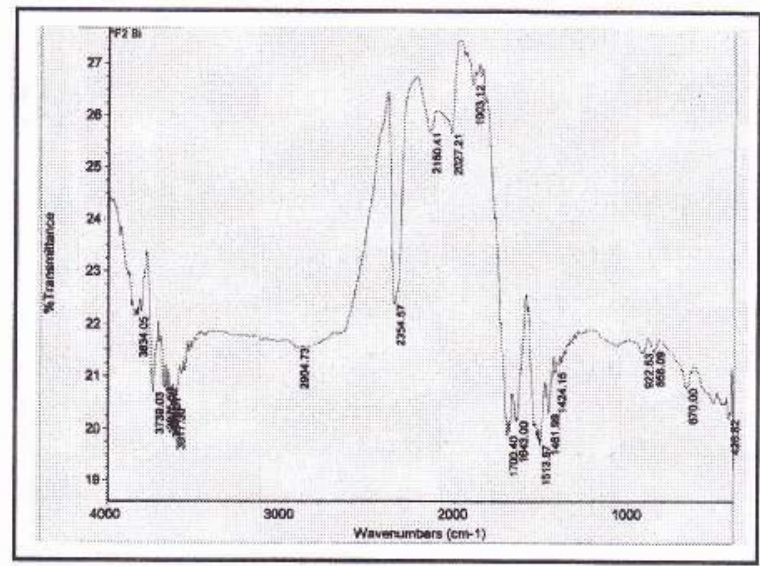

Gambar 9. grafik FTIR LDPE/tapioka $80 / 20$

MAH $4 \mathrm{phr}$ sesudah pemendaman dalam tanah

Dari 2 (dua) gambar tersebut diatas tampak bahwa tidak terjadi perubahan gugus gungsi sebelum dan sesudah pemendaman dalam tanah. Gugus fungsi yang ada: $\mathrm{O}-\mathrm{H}$ pada panjang gelombang 3739,03-3834,05 $\mathrm{cm}^{-1}$, gugus fungsi $\mathrm{C}=\mathrm{O}$ pada panjang gelombang $1643-1700 \mathrm{~cm}^{-1}$ dan gugus fungsi C-H pada panjang gelombang $1424,15-1461,99 \mathrm{~cm}^{-1}$.

\section{KESIMPULAN}

1. Makin lama waktu pemendaman dalam tanah sifat kekuatan tarik, kemuluran dan berat polipaduan LDPE/tapioka (MAH) makin turun.

2. Analisa spectrophotometer infra merah (FTIR) menunjukkan bahwa polipaduan LDPE/tapioka (MAH) sesudah pemendaman dalam tanah tidak terjadi perubahan gugus fungsi. Gugus fungsi yang ada yaitu: $\mathrm{O}-\mathrm{H}$ pada panjang gelombang $3739,03-3834,05 \mathrm{~cm}^{-1}$, gugus fungsi $\mathrm{C}=\mathrm{O}$ pada panjang gelombang $1643-1700 \mathrm{~cm}^{-1}$ dan gugus fungsi $\mathrm{C}-\mathrm{H}$ pada panjang gelombang $1424,15-$ $1461,99 \mathrm{~cm}^{-1}$.

3. Permukaan polipaduan LDPE/tapioka sesudah pemendaman dalam tanah yang diamati dengan Scanning Electron Microscopy (SEM) tampak tidak rata muncul lubang lubang.

\section{DAFTAR PUSTAKA}

Anonim. 2010. Produksi Plastik Dunia. AntaraNews.http://www.antara news.com/view/.diakses 11 Maret 2011.
Anonim. 1993. Projections of World Consumption Biodegradable Plastics in The Year. Chemical Week, October, 27.

Chan, C. M., 1994. Polymer Surface Modification and Characterization. Hanser/Gardner Publication, Inc., Cincinati, 1-5.

Choi, S. H., Hwang, Y. M., Ryoo. J. J., Lee, K. P., Ohta, K., Takeuchi, T., Jin, J. Y and Fujimoto, C., 2003. Surface Grafting of Glycidyl Methacrylate on Silica Gel and Polyethylene Bead. Proceedings of The APCE Meeting, Shanghai, China. October 11 - 1. Vol 24, Issue 18, pages 3181-3186.

Chandra, R. and Rutsgi, R.,1997. Biodegradation of Maleated Linear Low DensityPolyethylene and Starch Blends. Polymer Degradation and Stabilization. 56. 185-202.

Gupta, R.K.,1994. Handbook of Small Scale Plastics Projects \& Processing Techniques. Small Business Publication, Roop Nagar, Delhi-India.

Hasnah Muin. 2005. Memasukkan Gugus Fungsi pada Rantai LDPE untuk memudahkan degradasi. Institut Teknologi Bandung.

Indeerjeet Kaur dan Neena Gautam. 2010. Starch Grafted Polyethylene Evincing Biodegradation Behaviour. Malaysian polymer Journal. Vol 5 No1, p 26

Lies. Wisoyodharmo,Yelvia Deni, Doni A Winarto dan Syuhada. 2003. Pembuatan Plastik Ramah Lingkungan. Proseding Seminar Teknologi untuk Negeri, Vol 1 hal 361-370.

Luluk Mufidah, Fidyah Nanda Kusuma, Rindy Astri Wilujeng dan Choirul Anwar. 2008. Inovasi Pembuatan Plastik Ramah Lingkungan (Biodegradable) Berbahan Dasar Pati Jagung (Zea mays) Dan Chitosan (limbah Cangkang Udang). Laporan Akhir Program Kreativitas Mahasiswa, Universitas Negeri Malang. 
Maria Ulfa Christianty. 2009. Produksi Biodegradable Plastik Melelui Pencampuran Pati Sagu Thermoplastis dan Compatibilized Linier Low Density Polyethylene. Sekolah Pascasarjana Institut Pertanian Bogor.

Peacock, A. J., 2000. Hand Book of Polyethylene Structures, Properties and Applications. Marcel Dekker, Inc.

Sakai, K., N., Hamada and N.Y. Watanabe. 1987. Identification and Characteristics of Poly (vynil alcohol)-degrading bacterium. Journal of Macromolecul Science Kagaku to Kogyo 61: 372-377.

Scandola,M., 1995. Morphlogy and Biodegradation Behaviour of Polymer Blends Containing Bacterial Poly (3-Hydroxybutyrate) International Symposium on Boidegradable Polymers. Shinjuku Park Tower Tokyo, Japan.

Sunit Hendrana, Retno Yusiasih, Sudirman, Ipit Karyaningsih dan $\mathrm{Dj}$ imat Lisnawati. 2000 . Kopolimerisasi Tempel Anhidrid Maleat Pada Polietilen Dengan proses Blending untuk Plastik Ramah lingkungan. Prosiding Pertemuan dan Presentasi Ilmiah Penelitian Dasar Ilmu Pengetahuan dan Teknologi Nuklir, Yogyakarta 25-26 Juli.
Takashi Masuda, Akio Matsuda, Yasuteru Kajikawa, Kentarou Yamawaki, Ikuo Takahashi and Kenji Koumoto.1995. Synthesis and Biodegradation of Aliphatic Polyester. International Symposium on Boidegradable Polymers. Shinjuku Park Tower Tokyo, Japan. Tokiwa, Y., A. Iwamoto and M. Koyama. 1990 a. Development of biodegradable plastics containing polycaprolactone and or starch. Polymer Preprints American Chemical Society, Division of Polymer Materials Science and Engineering 63: 742-746.

Tokiwa, Y., T. Ando, T. Suzuki and T. Takeda. 1990b. Biodegradation of Synthetic Polymers Esters Bond. In: Proc. American Chemical Society, Division of Polymer Materials, Science and Engineering 62: 988992.

Thakore, I. M., Iyer, S., Desai, A. and Lee, A., 1999. Morphology, Thermochemical. Properties and Biodegradability of Low density Polyethylene/Starch Blends. Journal of applied Polymer, Science. 74. 2701-2802. 